\title{
Investigation On The Contributions Of People With Disabilities Of Present Laws İn Turkey And Level Of Utilization From The Law
}

\author{
Erkan GÜLGöSTEREN ${ }^{1 *}$, Mehmet Akif ZiYAGíliL ${ }^{1-2}$, Pervin TOPTAŞ DEMİRCi ${ }^{3}$, Ali DEMİRCi ${ }^{1}$ \\ ${ }^{1}$ Mersin University, Physical Education and Sport Sciences, Mersin/Turkey \\ ${ }^{1-2}$ Giresun Üniversity, Sports Science Faculty, Giresun / Turkey \\ ${ }^{3}$ Mersin University Erdemli Department of Tourism Animation, Turkey \\ *Corresponding author: egulgosteren@mersin.edu.tr
}

\begin{abstract}
Introduction: According to United Nations there are 650 million disabled people on the world. According to the results of World Disability Report more than one billion people lives with a disability. Disabled people and their family makes up one third of the world population. In this study, the goal is to determine the rate of the benefiting the rights provided by the present laws in Turkey. In this study the literature review method is used. Medline, Scholar, Google.com, Eric and Spor Bilimleri Magazine "disabled people", "laws for the disabled" and "disabled rights" is scanned with using the keywords. According to the findings; the rate of benefiting the rights provided by the laws is very low, the disabled people do not know their rights, they can not use the public transportation enough, and the municipalities do not organize the streets, avenues and roads considering the disabled. Also it is determined that the disabled do not benefit their rights enough in the areas of transportation, public life, social and health. Employment of the disabled, their working circumstances and their educational rights has gained acceleration but when it is compared to the disabled population it is inadequate. As a result: It could be said that individually and publically informing the disabled about their rights provided by the law would make an important contribution to the solving of the disabled people's problems.
\end{abstract}

\section{Keywords}

Disabled People, Laws, Disabled Rights

\section{INTRODUCTION}

Disability is an element of social exclusion. It is seen as a second obstacle for the handicapped to be prevented from social relations, cultural and social activities, access to basic services, close circles and economic fields. The concept of disability is a as concept that has communal, individual and social consequences in the literature (Genç and Çat G, 2013). A society consisting of individuals requires living together. Each individual acquires social identity through the role they assume when acting together with the community in which they are at an adequate level. The society participation level of the individual increases the satisfaction of living, which enables the person to overcome the problems (Subaşıoğlu, 2008). All people have equal rights and equal opportunities in educational opportunities, collective participation. However, in real life some

groups do not have rights in terms of social situations, cognitive and physical differences. The disabilities also in is constitutes a category of this group and the society is needs information on issues such as social welfare, vocational development, daily life, like other individuals (Subaşığlu, 2008).

Successful practices in the area human rights are often measured by the fact that services such as health, education, transport, social security, employment and justice are adequately provided to all individuals within the community, with or without disabilities. In this respect, the most important point regarding disabled people is to meet the needs of "creation of awareness" and "understanding" of disability in the society (Şahin, 
2004). According to research, the ratio of the total population of the disabled population in Turkey is $12.29 \%$ the proportion of disabled women $(13.45 \%)$ is more than that of disabled men (11.10\%) (Şibli, 2012; Abay and Güloğlu, 2015; Y1lmaz, 2012). Based on today's population, it can be said that there are more than 9 million disabled people in our country (Abay ve Güloğlu, 2015). According to the 2011 Demographic and Housing Survey results, rate the population with at least one disability (3 years of age and over) is $6.9 \%$ (4.876.000 people). This rate is $5.9 \%$ for males and $7.9 \%$ for females (Research Development and Project Directorate Statistics Bulletin January 2018).

Work has been done to increase the awareness of the community about the disability of the disabled potential and to improve their ability to meet their needs. The legal regulations, commissions and social activities created in this direction have become widespread both at the international and national levels. (Tütüncü ve Aydın, 2013). Disability can be mainly related to physical limitation or mental limitation (Tütüncü and Aydın, 2013, Özer, 2010). Despite the slow progress of academic studies carried out on this subject, it is possible to say that the academic and practical workings have increased due to the importance that the society has recently imposed on disabled people (Tütüncü and Aydın, 2013). This study "to determine the ratio of current laws in Turkey to benefit from the rights given to the disabled 'is intended

\section{MATERIALS AND METHODS}

Literature search method was used in the research. The articles published in Medline, Scholar, Google.Com, Eric and Sports Sciences magazines were scanned in the form of a combination of the words "disability", "disability law" and "disability rights" keywords. Then all the information is compiled and written descriptively.

\section{RESULTS}

According to the geographical regions, the distribution of the disabled population will be seen as the Marmara Region where the disabled population lives most intensively. Marmara Region is thought to be the most crowded region. It is expected that disabled population will be found more here than in other regions. What is striking in (Figure 1) is that the Black Sea Region is the place where the most disabilities are experienced after Marmara and Central Anatolia. Although the general population density is lower than the Aegean and Mediterranean regions in particular, as can be seen in (Figure1), the fact that the population with disabilities is high in this region is a fact to be considered on its own.

Figure 1. Numerical distribution of disabilities according to geographical area. (TÜİK, Nüfus ve Konut Araştırması, 2011)

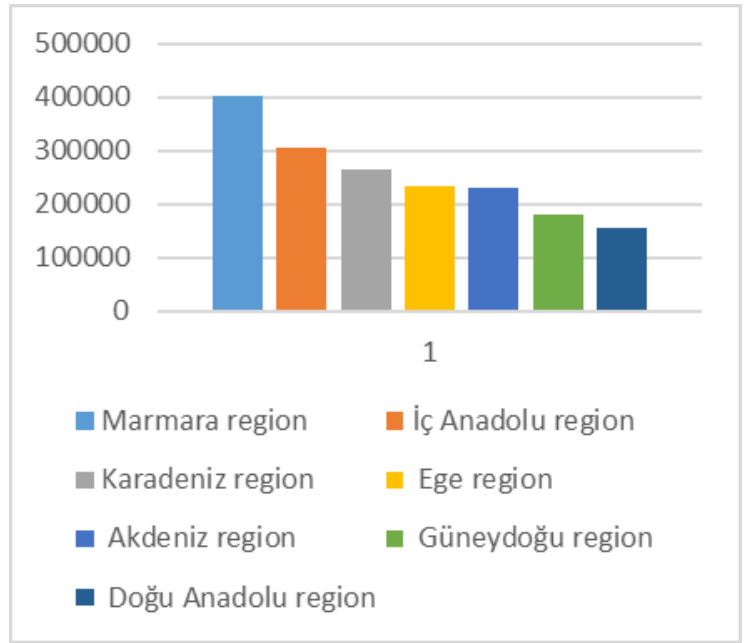

The most basic problem of disabilities is education. The lack of education of the disabled presents itself as one of the most important problems in front of integrating into society. According to the survey conducted by the Office of the Prime Minister's Office in 2002, it was observed that there was a great difference between the general population and the population of the disabled. According to the research dont know illiterate of Turkey's population $11.3 \%$ 'u, while the disabled population $34.1 \%$ has been determined illiterate. It is thought that a disabled population with no literacy and a low education level may have problems with employment. The proportion of the total population of the disabled population in Turkey is $12.29 \%$ (Şibli, 2012, Abay and Güloğlu, 2015, Y1lmaz, 2012). This is about 9 million people with disabilities. The number of civil servant and worker disability employment is quite low compared to general the population (Figure2). 
Figure 2: Employment of disabled population by years.(http://www.dpb.gov.tr/tr $\underline{\text { tr/istatistikler,2018) }}$

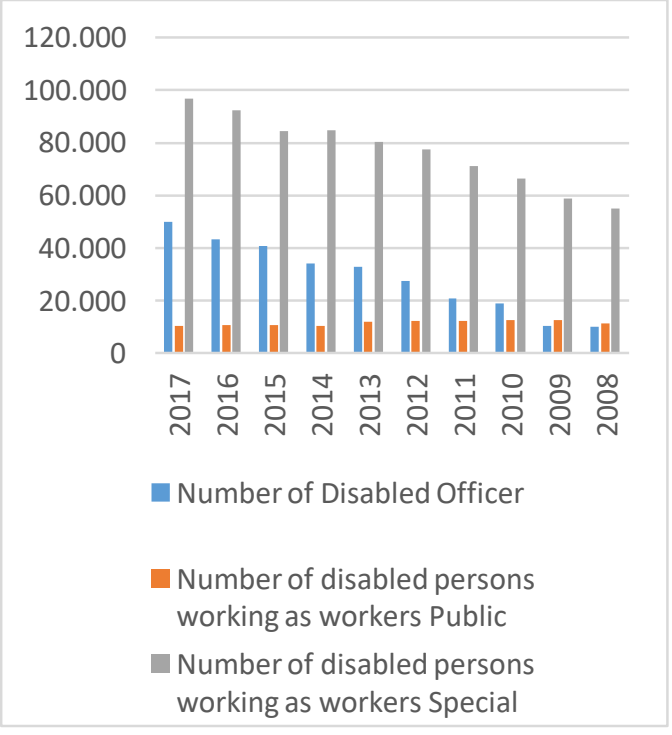

Tables 1 and 2 contain data on the social security situation of the disability. As can be seen, only half of the population with disabilities has social security. In addition, the proportion of those with social security in the handicapped also shows significant differences on a gender basis.

Table 1: Turkey's Social Security Distribution of the Disabled Population

\begin{tabular}{|l|c|c|c|c|}
\hline & \multicolumn{2}{|c|}{$\begin{array}{c}\text { Social Security } \\
\text { Status }\end{array}$} & \multicolumn{2}{c|}{ Enrollment Status } \\
\hline & Existing & $\begin{array}{c}\text { Non- } \\
\text { existent }\end{array}$ & Own behalf & Dependent \\
\hline Turkey & 47.55 & 52.45 & 45.21 & 54.79 \\
\hline City & 59.27 & 40.73 & 44.86 & 55.14 \\
\hline Rural & 35.15 & 64.85 & 45.84 & 54.16 \\
\hline Male & 44.84 & 55.16 & 67.96 & 32.04 \\
\hline Woman & 51.41 & 48.59 & 17.04 & 82.96 \\
\hline
\end{tabular}

According to the Turkey Disabilities Research Analysis Report, calculated ratio the be registered with the social security system. Similarly, in patients with continuous illness this rate is $86.42 \%$ for males and only $15.89 \%$ for females (Table 3 ).
Table 3: Turkey's as continuous Disease Population Social Security Status

\begin{tabular}{|l|c|c|c|c|}
\hline & \multicolumn{2}{|c|}{ Social Security Status } & \multicolumn{2}{c|}{ Enrollment Status } \\
\hline & Existing & Non-Existent & Own Behalf & Dependet \\
& & & & \\
\hline Turkey & 63.67 & 36.33 & 44.36 & 55.64 \\
\hline City & 70.80 & 29.20 & 45.23 & 54.77 \\
\hline Rural & 50.28 & 49.72 & 42.06 & 57.94 \\
\hline Male & 62.40 & 37.60 & 86.42 & 13.58 \\
\hline Woman & 64.56 & 35.44 & 15.89 & 84.11 \\
\hline
\end{tabular}

According to the 2002 Turkey Disability Survey, questions were asked about the situation of disabled people to benefit from the 6 basic services. As Table 4 shows, $55.7 \%$ of the respondents said that they benefit from health services. It is seen that half of the disabled people can not benefit from health services.Since disability is simply perceived as a "health problem", health services appear to be at the forefront and important than other services. On the other hand, for example, when health services are offered relatively more, it is necessary to question the reasons for the low level of care and rehabilitation services, which are important and integral parts of health services (Table 4).

Table 4: Services and Benefits Status

\begin{tabular}{|lcc|}
\hline Services & \multicolumn{2}{c|}{ Leveraging unserviced } \\
& $\%$ & $\%$ \\
\hline Health Care & 55,7 & 44,3 \\
Educational Service & 12,27 & 87,73 \\
Care And Rehabilitation Service & 5,9 & 94,1 \\
Occupation And Skill & 1,0 & 99,0 \\
Acquisition Course & & \\
Family Guidance And & 1,0 & 99,0 \\
Counseling & & \\
\hline Social And Cultural Services & 0,9 & 99,1 \\
\hline
\end{tabular}

According to the graph, public transportation services, which can be considered as one of the indicators of reaching the public space, are not sufficient. Only 4\% say they benefit from this service. One of the notable points is the high rate of absence of public transport in the area. However, another important issue here is that you are not aware of the existence of this service. Approximately $20 \%$ of persons with disabilities are not aware of the availability of public transport (Figure 3). 
Table 2: Turkey's recorded of Disability Population Social Security Distributio

\begin{tabular}{|l|c|c|c|c|c|}
\hline Social Security Institution & Physically Disabled & Visually Impaired & Hearing İmpaired & Speech İmpaired & Mentally Disabled \\
\hline Social Security & 234079 & 97796 & 76687 & 73554 & 74089 \\
\hline $\begin{array}{l}\text { Employee Government } \\
\text { Organization }\end{array}$ & 37674 & 21009 & 10605 & 10837 & 13564 \\
\hline Pension Fund & 42368 & 23426 & 14227 & 8423 & 13633 \\
\hline Bağ-Kur & 104143 & 49358 & 28750 & 25574 & 28815 \\
\hline Green Card & 108051 & 51900 & 29735 & 35922 & 45484 \\
\hline Private Health Sig. & 1937 & 967 & 729 & 0 & 380 \\
\hline Special Crate & 430 & 1237 & 205 & 0 & 410 \\
\hline Under The Law 2022 & 12498 & 6670 & 4706 & 3390 & 5916 \\
\hline Other & 18748 & 10384 & 5807 & 6374 & 11013 \\
\hline Total Saved & 522254 & 241738 & 160846 & 153237 & 179740 \\
\hline Total Disabled & 857631 & 412313 & 252810 & 263007 & 331242 \\
\hline $\begin{array}{l}\text { Total Number Of Disabled } \\
\text { People }\end{array}$ & 297703 & 149566 & 81359 & 98933 & 137938 \\
\hline
\end{tabular}

Figure 3: Rates of public transport services in where vicinity

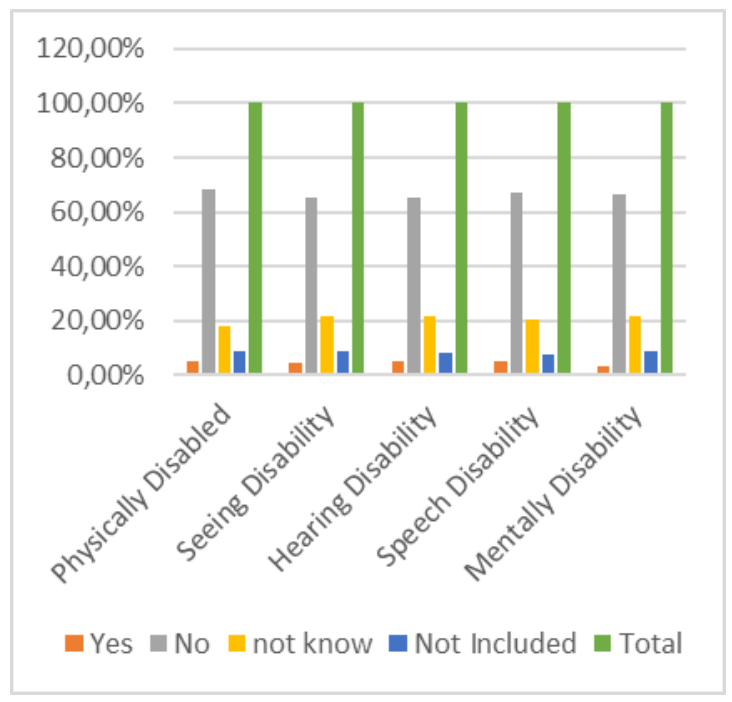

Figure 4 is a question of whether the building, street, roads and roads in which the individual with a disability lives are arranged according to the obstacle. Therefore, those who stated that the regulation is around; $3 \%$ for physical disabilities, $2.6 \%$ for visual disabilities, $2.3 \%$ for hearing disabilities, $3.1 \%$ for speech impaired, and $1.8 \%$ for mental disabilities. Regardless of the type of disability, in general, $68 \%$ of people with disabilities live in an environment where there is no regulation due to an obstacle. In addition, $20 \%$ of the handicapped have no information on this issue.
Figure 4: Arrangement of buildings, streets, streets and roads acording to disabilities

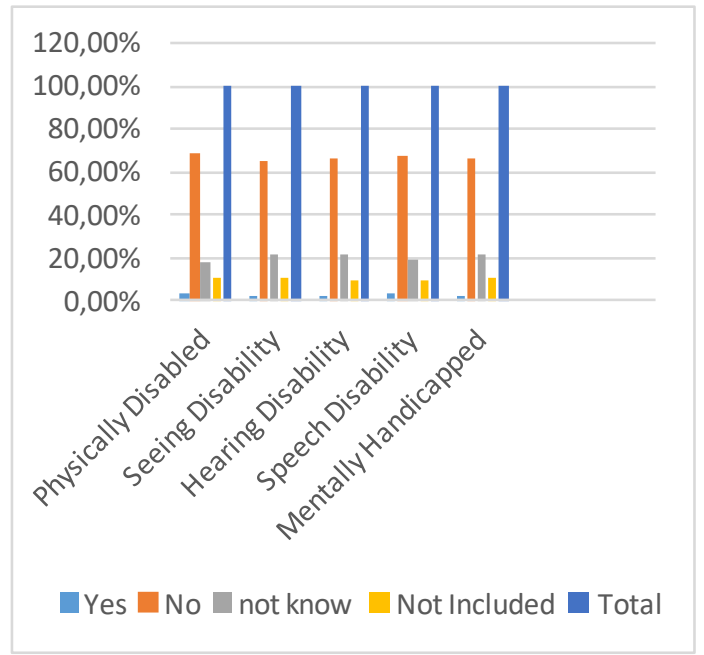

Under public sector benefits that disabled people can benefit from within the scope of the discount (Figure 5). In addition, city buses, underground services, TCDD and sea routes are free of charge. Special discounts are applied for mobile phone services, medical equipment purchases, physiotherapy sessions, state theaters, museums and places of disability. In addition to these, rights such as education, accessibility, car park, special excise tax, MTV, and disabled salary are utilized. 
Figure 5: Services provided

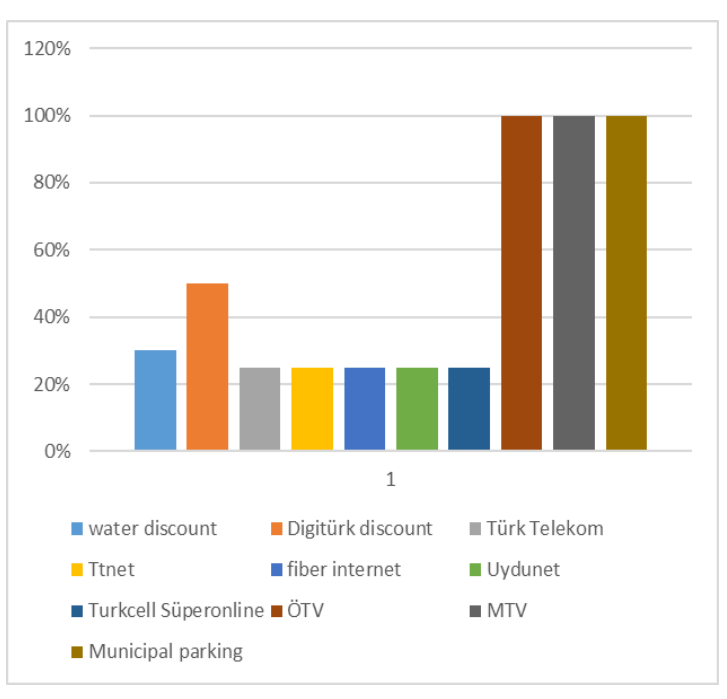

\section{DISCUSSION AND CONCLUSION}

It is a right to know the existence of disabled people in society and to prepare independent living conditions. Utilization this right every individual without discrimination is a necessity to be a social and powerful state. To remove the social disadvantages of persons with disabilities, and to provide them with the services needed to live a life that suits human dignity; is the duty of the state, which is responsible for reducing the welfare differences between the individual, guaranteeing human life for all (Seyyar, 2001). It is this a fact that; all the services and efforts but it will meaning sense when the general public is sensitive to the needs of disabled people. This can only be possible if the community is informed about the problems of the disability. According to thinkers in the current social model, disability is not individual but a social issue at the same time. Problems arise because disabled people do not recognize their rights because the society they are involved with excludes them and does not offer equal opportunities to them (Altuntaş and Topcuoğlu, 2014).

It is one of the most important social services of the state to eliminate the social disadvantages and to ensure the participation of the disabled people in the social life in equal opportunity with the other individuals. Struggling with social disadvantages and discrimination is an important aspect of defending human rights. It aims to combat discrimination, to protect the prohibition of discrimination and to pass on the principle of equality. Despite the presence of many national or international laws and sanctions created for the prevention of discrimination, not only the agenda of Turkey but alsso the world's occupying a serious human rights problem. These measures on the legal level are undoubtedly important. However, they can not pass to life unless they are actively supported on the social level (Y1lmaz, 2012, Beyazova, 2012). Employment is the basic way of socializing for disabled people. Business life is at the center of our lives and it is very important for healthy individuals as well as for disabled people to earn income and socialize. People will contribute economically by taking part in working life. People in working life will feel productive. Besides self-confidence and sense of identity, they are more active in social relationships outside the home and feel themselves better psychologically. It is the natural right of people with disabilities as well as all people to be able to benefit from the opportunities for disabled people to work on equal opportunities, to be a business owner, and to live independently from the socio-economic front.

In the event that the obstacles of the disabilities are tried to be eliminated or it is not possible to do so, it is necessary to provide them the necessary financial and spiritual possibilities for their lives. Unlike quota regime in employment, employing alternative employment models can increase employment rates. As a result; it can be ensured that jobs in certain occupational areas are allocated to the disabled. Encouragement of disability to set up their own business can provide employment for more disabilities. Employment planning should be based on competencies rather than shortcomings. Employment rates of services and barriers to determining the development and social development of an country are considered as one of the important criteria. This rate should be increased. Identification and job analysis of the obstacle group should be standardized by determining which obstacle groups can do which tasks. In this way, it will not be left to the initiative of the managers to do what the disabled employees do. 
Protected workplace practices should be passed on. Job descriptions should be done taking into consideration the obstacle reports. Employers should be encouraged with courses and trainings and awareness levels should be increased

\section{REFERENCES}

Abay AR and Güloğlu Kahraman F (2015). The content analysis of basic national legal legislation from the point of gender, The Journal of International Social Research cilt: 8 sayı: $40 \quad$ volume: 8 issue: 40

Altuntaş B and Topcuoğlu R (2014). Home care service on the rights of persons with disabilities, caregiving and social sex based work section, VI. National Symposium on Social Rights, Ankara

Beyazova A (2012). The role of civil society organizations in the challenge of discrimination 2 discrimination: multidimensional approaches, istanbul Bilgi University sociology and education studies unit, İstanbul.

Demir F (2005). Introduction to constitutional law general principles and turkish constitutional law, 6. Bask1, Anadolu Matbaacilık, s. 220. İzmir

DİE ve Başbakanlık Özürlüler İdaresi Başkanlığı (2002). Research and development and project directorate statistics bulletin january 2018 statistical information on disabled and elderly individuals.

Genç Y and Çat G (2013). Employment of disabled people and social inclusion relationship, Journal of Academic Inquiries Cilt/Volume: 8, Say1/Number:1

Özbudun E (1992). Turkish constitutional law, 2.Baskı, Yetkin Yayınları s. 99, Ankara

Özer DS (2010). Physical education and sports for the disability, Nobel, Nisan Ankara

Özürlü ve Yaşlı Hizmetleri Genel Müdürlüğü (2011) :12

Sözer AN (1991). Social Insurance Relationship, Dokuz Eylül University Yayınları No:0906, İzmir, s. 4.

Seyyar A (2001). Struggle against disability in terms of social policy, Türdav Basin Yayın İstanbul

Subaşığlu F (2008). A study on "disability awareness" of information and document management departments of universities information world, $9 \quad$ (2):399-430
Sahin H (2004). Who is the problem with disability? Is it individual or society? Devotion, ss. 40-50

Şibli G (2012). Tax Arrangements and Financial Solutions for Disabled Citizens, Ocak-Şubat 2012.

Tanör B and Yüzbaşığlu N (2001). According to 1982 constitution, turkish constitution law, 2. Bask1, Yap1 Kredi Yayınları, s.167 ve s.96.

Tütüncü Ö and Aydın C İ (2013). Dokuz eylül university sports science and technology college recreation department anatolia: Turizm Araştırmaları Dergisi, Cilt 24, Sayı 2, Güz: $261-263$. 